\title{
Analysis of Onion Market Value Chain Among Smallholder Farmers in Rural Ethiopia: A Case Study of South Bench Woreda in Bench Maji Zone, Ethiopia
}

\author{
Tesfaye Zeleke ${ }^{1} \quad$ Negese Tamirat ${ }^{2}$ \\ 1.Tesfaye Zeleke: Department of Economics, Mizan-Tepi University, Mizan, Ethiopia \\ 2.Negese Tamirat: Department of Economics, Jimma University, Jimma, Ethiopia
}

\begin{abstract}
This study analyzed value chain analysis of onion market in south Bench Woreda. The data used for the study were obtained from 118 randomly selected samples of households and 65 sample of trader in the study area. The data for the study was collected from both primary and secondary sources. For the primary data collection, questionnaires was designed and pre-tested based on the objective of the study in the study area. The questionnaires schedule was tested at the farm level on 5 randomly selected farm households. The study was employed both descriptive and econometric data analysis methods. Cobb-Douglas production function model was employed to analyze the determinants of onion production supplied to the market by onion producers. Results of econometric model showed that quantity of fertilizer utilized, distance from the nearest market, family size of house hold head, educational level of house hold head, farming experience and Credit access were significantly and positively determined the quantity of onion supplied to the market. The results suggest that these significant variable need to be promoted to boost the amount of the onion market supply. In order to increase the productivity of onion there is need of public, private, research center and farmer themselves working together so as to increase access and disease resistance seed verity.

Keywords:Onion Value Chain Analysis, Marketing Channel, Cobb Douglas Production Function Model, South Bench Woreda.
\end{abstract}

DOI: $10.7176 / \mathrm{DCS} / 11-8-02$

Publication date:October $31^{\text {st }} 2021$

\section{Introduction}

In Less Developed Countries (LDCs) in general and Sub-Saharan Africa (SSA) in particular, economic policy highly depended on agriculture. Poverty reduction and income growth can mainly be achieved by agricultural growth. It creates spillover effects to the remaining sectors [1]. Agriculture is Ethiopia's most important sector, basis for the country's food security and the livelihoods of nearly $85 \%$ of its people. It holds about $50 \%$ of the Gross Domestic Product (GDP), 90\% of the total export revenue, $85 \%$ employment of the country's labor force and it also accounts $70 \%$ of raw materials requirement of the country's industries [2], but also the engine for the country's Agriculture Development Led Industrialization (ADLI) strategy.

Vegetable production is an important economic activity in agricultural sector ranged from home gardening small holder farming to commercial farm owned both by public and private enterprise. Ethiopia has variety of vegetable crops, grown in different agro ecological zone produced through commercial as well as small holder farmer as both source of income as well as a sustainable food security [3]. Smallholder vegetable farms were based on low input- output production systems, use of improved seeds, planting material of high yielding varieties and other inputs such as fertilizer, technical training and extension services on improved crop husbandry techniques are not available a result average productivity levels are low in the small scale farming sector [4].

Onion is considered as one of vegetable crops produced on large scale in Ethiopia, and occupied an economically important domicile among vegetables. The area under onion is increasing from time to time mainly due to its high profitability per unit area and ease of production, and increases in small scale irrigation areas. The crop is produced both under rain fed in the meher season and under irrigation in the off season. In many areas of the country, the off season crop constitutes much of the area under onion production. The total areal coverage of onion crop in the country was $21,865.4$ ha, with total production of $219,188.6$ tons with average productivity of 10.02 tons/ha [5].

According to [6]result revealed that the market-oriented farmers play a significant role in the rural agricultural sector. However, these trader-farmers are often disadvantaged by limited access to information, services, appropriate technology and capital. These factors restrict their capacity to effectively participate in the marketing of their produce. Therefore, they end up earning little margins while giant chain actor's along the chain like middlemen have the power to determine prices paid by the final consumer and thus extract huge marketing margins.

Value chain analysis of horticultural crops conducted by [7] in Kombolcha Woreda identified different production and marketing problems and the gross margin obtained by different actors. The study conducted by [8], result showed that in Malawi and Mozambique on value chain analysis of traditional vegetables found out lack of 
contract arrangements, low demand for inputs, lack of capital, poor infrastructure, low producer and market prices, lack of processing services, poor packaging materials and services, poor seed quality, were factors that future interventions should address for the entire value chain and analysis of value chain constraints. Another constraint in the value chain is that farmers are, for various reasons, not applying the recommended Good Agricultural Practices (GAP).

Despite the significance of value chain of onion market in the livelihood of many small farm households and income generating value chain of onion crop in the study area, it is only recently that few studies have been done on value chain of onion market. However, most of these studies have focused on marketing margins, gender role, opportunities and constraints, and factors affecting participation, and extent of participation of farmers in the value chain. Systematic and adequate information on the process of value chain of onion market not well identified. Further, in the study area there is no empirical study conducted on value chain of onion market. Therefore, this study was conducted to assess the value chain of onion market in south bench Woreda.

\section{Literature Review}

\subsection{Theoretical Review}

Value chain: a chain of activities that is associated with adding value to a product through production and distribution processes [9]. The goal of company is to deliver maximum value to the end user at least possible cost to the company to maximizing profit. Approach of value chain was developed by Michael Porter in the 1980s, and described in his book Competitive Advantage, Creating and Sustaining Superior Performance. His idea was to divide a business into its strategic activities to make them better than the rivals. It is the full range of activities that is required to bring a product from conception, through the different phases of production and transformation and made up of a series of actors from input suppliers to exporters [10]. Value chain analysis focuses on changes over time in the structure, conduct and performance of value chains, particularly in response to changes in market conditions, technologies and policies [11].

A fundamental aspect of global value chain research was, how value itself, is conceptualized and measured. The analysis of these structures answers to a set of questions like how does the production process take place, who participates at the stage? Where do different stages take place? How are they linked, who benefits? These answers are required to find the pertinent points of intervention for a successful integration of poor population sections [12]. According to [10] there were four steps of value chain analysis were applied. i. Mapping the value chain to understand the characteristics of the chain actors and the relationships among them, including the study of all actors in the chain, of the flow of vegetables through the chain, of employment features, and of the destination and volumes of domestic and foreign sales. This information can be obtained by conducting surveys and interviews as well as by collecting secondary data from various sources. ii. Identifying the distribution of actors' benefits in the chain. This involves analyzing the margins and profits within the chain and therefore determined who benefits from participating in the chain and who would need support to improve performance and gains. In the prevailed context of market liberalization, this step is particularly important, since the poor involved in value chain promotion were the most vulnerable. iii. Defining upgrading needed within the chain. By assessing profitability within the chain and identifying chain constraints, upgrading solutions could be defined. These may include interventions to: (a) improve product design and quality and move into more sophisticated product lines to gain higher value and/or diversify production; (b) reorganize the production system or invest in new technology to upgrade the process and enhance chain efficiencies; (c) introduce new functions where in the chain to increase the overall skill content of activities; and (d) adapt the knowledge gained in particular chain functions in order to redeploy it. iv. Emphasizing the governance role. Within the concept of value chain, governance defines the structure of relationships and coordination mechanisms that exist among chain actors. By focusing on governance, the analysis identified actors that may require support to improve capabilities in the value chain, increase value added in the sector and correct distributional distortions. Thus, governance constituted a key factor in defining how the upgrading objectives could be achieved.

\subsection{Status of onion Value chain analysis and Production in Ethiopia}

Ethiopia is country differentiated by agro - climatic condition that makes it suitable for the production of a broad range of fruits and vegetables; altitude, level ranging from below sea level to over 3000 meter above sea level and gives it a wide range of agro ecological diversity ranging from humid tropics to alpine climates, where most types of vegetable crops can be successfully grown [13].Commercial production of horticultural crops, including vegetables, has also been increasing in recent years because of expansion of state farms and increasing private investment in the sector by national and international entrepreneurs [4]

Among this crop onion considered as one vegetables crop produced on large scale in Ethiopia for both commercial and consumption purposes, and grows well under mild climatic conditions without extreme heat or cold or excessive rainfall [14]. Onion was introduced to the agricultural community of Ethiopia in the early1970s when foreigners brought it in, currently; the crop is produced in different parts of the country for local consumption 
and for export of flowers to European markets [15].In recent years, the demand for onion increased for its high bulb yield, seed and flower production potential. The establishment of state owned enterprises contributed substantially to the increase in the production and expansion of area under onion in the country with limited amount of seed production experiences. Onion seed production depends on the cultivar, location, growing season and adequate plant protection measures [16].

However, yet the production of the crop is not exploited due to the production and productivity of the crops are dependent on the potential of genetic factor of the individual crops and the environment where it has been grown [17]. Even if, the country has a great potential to produce onion every year for both domestic and export market, other problems affect the marketing activities of onion produce in Ethiopia. Some of them are price fluctuation or low pricing at peak supply period, lack of standards for produce, lack of coordination among producers, inadequate availability of market research and marketing information, weak linkage in the chain, lack of storage facilities and poor road access [18].

\subsection{Empirical Review}

As different literatures indicate that the study conducted in the field of market and value chain analysis on different agricultural product, some of them are described as follow: Studies conducted by [19], indicted that absences of research and market information in Ethiopian, leads value chain of honey wasted infinite benefits. This study was further evidenced by [20], who stated that, lack of government support such as, inadequate research and training, lack of policies and strategies have increased knowledge gap among the Ethiopian small-scale farmers. Study conducted by [21] state that low level of improved agricultural technologies, risks associated with weather conditions, diseases and pests, and increasing population pressure the land holding per household is declining leading to low level of production to meet the consumption requirement of the household.

According to[22]marketable supply of malt barley was significantly affected by output of malt barley, selling price, market information and distance to the market by applying two stages least squares (2SLS) regression model.[23] Conducted study on factors affecting milk market participation and volume of supply in Ethiopia by using Heckman two-stage selection model, the study showed that milk yield per day, dairy farming experiences and numbers of members in household significantly affected volume of milk supply. According to the study of [24] identified factor affecting the marketable surplus of fruit by using OLS regression model and the result of the study indicated that education level of house hold head, quantity of fruit produced, fruit production experience, extension contact, lagged price and distance to the market place were affecting the marketable surplus of fruit. The study conducted on onion, determinants of onion supplied to the market using Tobit model and the results of the study indicatedthat non-farm income of the households, total land size of the households, total quantity of onion produced and access to credit services affected positively and significantly the quantity of onion supplied to the market while total family size showed significant and negative relation with quantity of onion supplied to the market.

As[25], gender, educational status of house holds together with access to free aid, Agricultural extension service, market information, none farm house hold income, adoption of modern livestock input, volume of sale and time spent to reach the market have statistical significant effect on whether or not a farmer participate in livestock market and his/her choice of marketing channel. They used binary logit and multinomial logit model to explore the patterns and determinant of small holder livestock farmer market participation and market channel choice using micro level survey data from Ethiopia. Study Conducted by [26],on determinants of choice of marketing outlets for African indigenous vegetables among the agro-Pastoral Maasai of Narok and Kajiado counties of Kenya using multinomial logistic regression model, the study pointed that quantity of African Indigenous Vegetables sold, agricultural market distance, sex, educational level, household size, levels of value addition, farming experience in agro-pastoralist, off-farm income and marketing costs are the main factors that affecting choice of marketing outlet by the agro-pastoral.

In Zambian smallholder bean producer identified that factors affect choice of marketing channels by adopted a probit model. Results from such model indicated that the choice of marketing channel were directly affected by the price of beans, scale of operation (as measured by the quantity of beans harvested, and quantity sold), distance to the market, farming mechanization used and livestock ownership [27]. On the other hand, modal results for decision to sell indicated that price mechanization and farmers age significantly affected farmer decision, meaning that price was very important factor in stimulating both selling decisions and channel selection. According to the study of [28], employed using multiple liner regression models and estimated that educational level of house hold head, market information, and distance to the nearest market, extension service, and quantity of fruit produced were significantly affected marketable surplus of fruit. A study conducted in Darolebu district of Oromia region on factor affecting vegetable supplied to the market, using Tobit model, showed that irrigation access, farming experience and total land cultivated in vegetable production were significantly affected vegetable supplied to the market [29].

As [30] identified factor affecting potato market participation of farmer and extent participation of farmer in 
Hadiya zone, Ethiopia by using Heckman sample selection model and the result of the study showed that sex of house hold head, extension service, credit access, tropical livestock unit, lagged price and number of oxen were significant factor for volume of potato sold.[31], stated that access to market information, farm size, education level, access to credit, membership to an organization and distance to the nearest market significantly affected market participation decision of haricot bean producers. Accordingly, the extent of market participation among haricot bean producers was significantly affected by farm size and access to credit.

\subsection{Conceptual Framework}

Identification of actors and channels related to production and marketing of onion were presented in a conceptual framework, based on theoretical concepts and empirical studies. The production process was start from at the stage of input supply, then covers to production by producer, processing and marketing by trader and ends up with the consumption of a certain product by consumer. Quantity of onion production supplied to market were influenced by several expected variables, such as Personal factors: age of house hold head, sex of household head, family Size of household head, education level of household head and farming experience of household head; Institutional factors: distance from the nearest market, Credit access, Extension service and Irrigation Access; Economic Factor: Farm size allocated and Fertilizer applied. The conceptual frame work for onion value chain presented in Figure .1

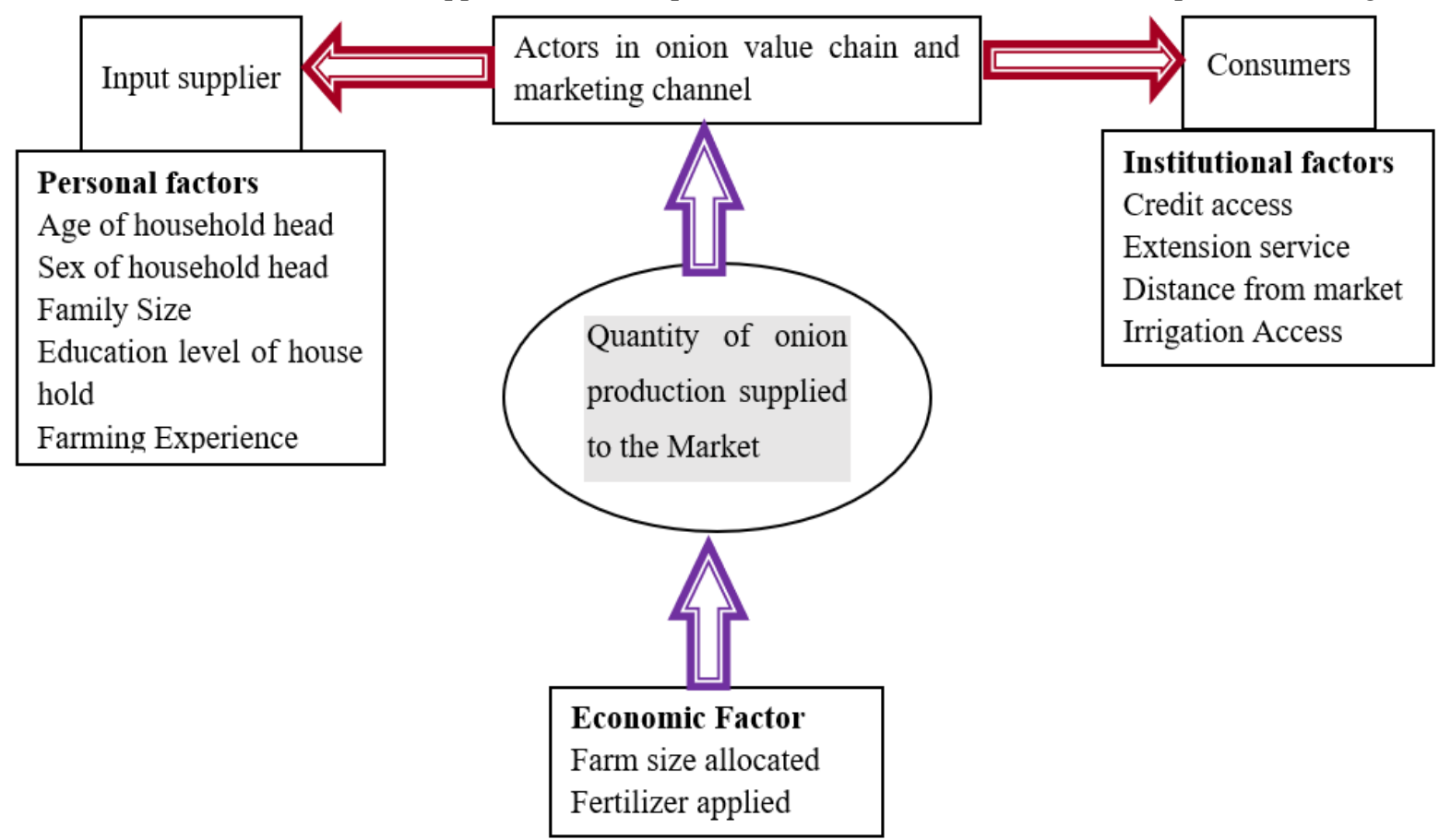

Figure 1: Conceptual framework of the study

\section{Methods}

\subsection{Description of the Study Area}

The study was conducted in South Bench Woreda in Bench Maji Zone, Southern Nations, Nationalities and Peoples Regional state (SNNPRS), Ethiopia. South Bench Woreda is located in South Nations, Nationalities, People's Region (SNNPR), in the South West central part of Ethiopia about a distance of $592.5 \mathrm{Km}$ south of Addis Ababa, $867 \mathrm{~km}$ from regional city, Hawassa, in the South West and $27.5 \mathrm{~km}$ from the Zonal Town, Mizan-Aman, and geographically located between $6.73^{0}-7.01^{0} \mathrm{~N}$ latitude and 35.37.36.7 $\mathrm{E}$ longitudes (figure 2). Total populations in the Woreda were 132,535, out of this, 11,178 were males and 121,357 were females. The Woreda have three ecological zones, Kolla (5\%), Woynadega (80\%) and dega (15\%). The amount of annual rainfall ranges from 1,801 up to $2000 \mathrm{~mm}$ and amount of temperature ranges between $15.10^{\circ} \mathrm{c}-25^{\circ} \mathrm{c}$. 


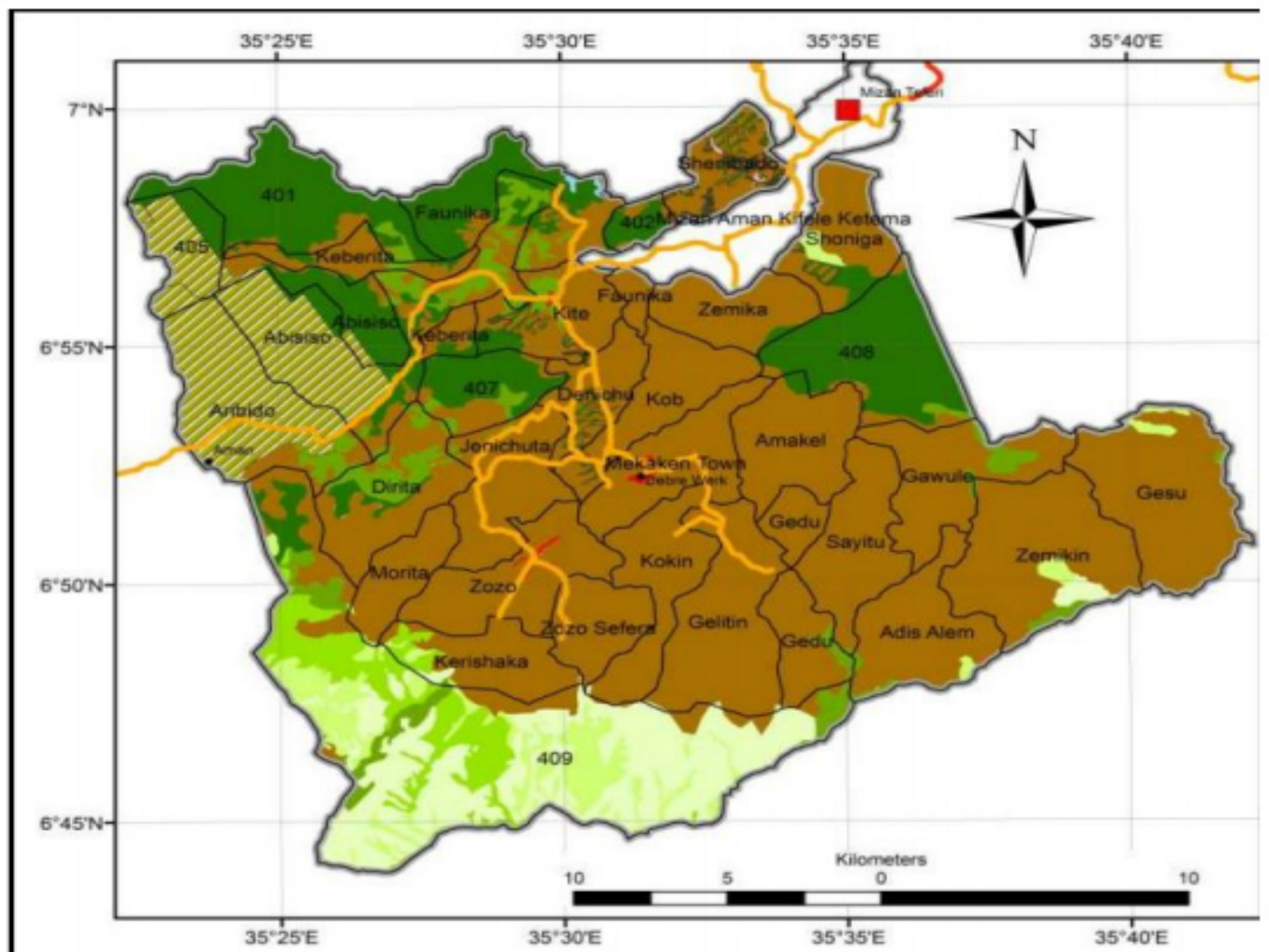

Figure 2: Map of the study area

The economy of the Woreda depends on cereal crop, vegetable crop, pastoralist, fruit and natural forester. Among the vegetable crop onion contribute the largest share and used for both generations of income and house hold consumption purpose. The total land area of the Woreda is 255,099 ha. Out of this total land area, 46,378.25 ha were covered by agricultural land, 9375 ha were covered by pastoralist, 15,243 ha were covered by natural forest, 47,176 ha were covered by fruit and other crop and 385.5 ha were covered by onion crop.

\subsection{Sampling Techniques}

A multi stage sampling procedure was applied to select the sample kebeles and sample households. The study applied both non-probability and probability sampling techniques to select the sample from a given population. In the first stage: Out of the total of Woreda in Bench Maji zone, South Bench Woreda was purposively selected, because of its amount and volume of production, accessibility and communication. In the second stage, take into account the resource available, five kebeles (Gelitin, kerishaka, Gedu, kokin and Kashu) were selected from 27 onion producing kebeles based on their agro ecological zone. In the third stage a list of onion producer was prepared for each selected Keble and Respondents were selected by simple random sampling method, and sample size was determined and allocated to each selected kebele through proportionately. The survey was carried out in the months of May and June 2018. The sample size was determined based on the simplified formula given by [32]. Where $\mathrm{n}=$ the sample size, $\mathrm{N}=$ the population size, and $\mathrm{e}=$ the level of precision. $\mathrm{N}=$ the total number of households in the selected Kebeles (3000 HHS), and e= acceptable error margin 9\%. It could be calculated by using above formula:

$$
\begin{aligned}
\mathrm{n}= & \frac{\mathrm{N}}{1+\mathrm{N}\left(\mathrm{e}^{2}\right)} \\
& \mathrm{n}=\frac{\mathrm{N}}{1+\mathrm{N}(\mathrm{e}) 2}=\mathrm{n}=\frac{3000}{1+3000(0.09) 2}=118
\end{aligned}
$$

After determining the total sample size of selected kebeles, then determining the stratified sample size of each selected kebeles proportionally:

$$
\mathrm{n}_{\mathrm{i}}=\frac{\mathrm{N}_{\mathrm{i}}}{\mathrm{N}}(\mathrm{n})
$$

Where $\mathrm{n}_{\mathrm{i}}$ is the total number of sample household from each $\mathrm{i}^{\text {th }}$ selected kebele, $\mathrm{N}_{\mathrm{i}}$ is the total number of household in the $\mathrm{i}^{\text {th }}$ kebeles, $\mathrm{N}$ is the total number of households in the selected kebeles and $\mathrm{n}$ is the total sample size. 
Table 1.Sample of onion producer in five selected Keble

\begin{tabular}{llcc}
\hline No. & Selected Keble & $\mathbf{N}_{\mathbf{i}}$ (onion producers) & $\mathbf{n}_{\mathbf{i}}$ (onion producers) \\
\hline \hline 1 & Gelitin $\left(\right.$ kebele $\left._{1}\right)$ & 600 & 24 \\
2 & Kerishika $\left(\right.$ kebele $\left._{2}\right)$ & 700 & 26 \\
3 & Gedu (kebele $)$ & 520 & 20 \\
4 & Kokin $\left(\right.$ kebele $\left._{4}\right)$ & 750 & 30 \\
5 & Kashu (kebele & 430 & 18 \\
& Total & 3000 & 118 \\
\hline
\end{tabular}

\subsection{Data Collection}

The data for study was collected from both primary and secondary sources. Cross- sectional data was employed from the randomly selected sample farmers. For the primary data collection, specifically questionnaires were designed and pre-tested based on the objective of the study. The questionnaires schedule was tested at the farm level on 10 randomly selected farm households. In the light of pre-testing, essential amendments were made on the wording and statements. Furthermore, the pre-test enables to know whether farmers have clearly understood the interview schedule. The primary data collection included households' demographic and socioeconomic characteristics. Secondary data was collected from relevant literatures, reports of Agricultural and Rural development offices and other publications. After, this both quantitative and qualitative information was collected to respond for raised questions around studying area as well as others onion producers.

\subsection{Methods}

To conduct this study both descriptive and econometric model were used for data analysis. Descriptive statistics were used to analyze the data that were collected from different sources in the form graph, table and to find frequency, mean, percentage, maxi, min and standard deviation.

\section{Analysis of onion marketing performance}

Marketing margin analysis is analysis which deals with comparison of price at different level of marketing chain over the same period. It measures the share of final selling price that is captured by particular agent in the marketing chain and always related to the final price, expressed in percentage [33]. Total gross marketing margin (TGMM) is always related to the final price paid by the end buyer and is expressed as percentage [33].

$$
T G M M=\frac{\text { Consumerprice }- \text { producerprice }}{\text { consumerprice }} \times 100
$$

Where TGMM is the total gross marketing margin, it is useful to introduce the idea of farmer portion or producer gross marketing margin, which is the share of price paid by consumer that goes to the producer. To find the benefit of each actor the same concept will be applied with some adjustment. For the analyzing margin first total gross marketing margin will be calculated. The producer gross marketing margin calculated as:

$$
\begin{gathered}
G M M P=\frac{\text { Consumerprice }- \text { marketin gross margin }}{\text { consumerprice }} \times 100 \% \\
G M M P=1-T G M M \quad \text { Or } G M M i=\frac{\text { sSi-ppi }}{\mathrm{TGMMi}} \times 100
\end{gathered}
$$

Where $\quad \mathrm{GMM}_{\mathrm{i}}$ is the marketing margin at given stage, $\mathrm{SS}_{\mathrm{i}}$ is the selling price at $\mathrm{i}^{\text {th }}$ link and $\mathrm{PP}_{\mathrm{i}}$ is the purchase price at $\mathrm{i}^{\text {th }}$ link. GMMi: is gross marketing margin at each stage

$$
P S=\frac{P x}{\operatorname{Pr}} \times 100=1-\frac{M M}{\mathrm{pr}} \times 100
$$

Where, PS is Producer's share, Px is producer price of onion, PR is Retailer price of onion and MM is Marketing Margin

\section{Econometric model}

In the production analysis a farmer uses amounts of inputs (such as labor, seed, fertilizer, ) to produce onion output. The production function shows the maximum amount of the output that can be produced using alternative combinations of labor, seed, and fertilizer and given the socio economic, environmental characteristics and institutional services. Such type of production relationship can be expressed using Cobb-Douglas production function. Cobb Douglas production functional form econometric model were specified as:

$$
\gamma i=\mathrm{A} \chi \mathrm{i}^{\mathrm{bi}} \mathrm{e}^{v t}
$$

Where: $\mathrm{Y}_{\mathrm{i}}$ is Dependent variable (quantity of onion production supplied), $\mathrm{X}_{\mathrm{i}}$ is explanatory variable, $\mathrm{b}_{\mathrm{i}}$ is Coefficients to be estimate or total factory of productivity, $\mathrm{e}$ is Natural logarithmic and $v t$ is Disturbance term or error term. The generalized transformed form of the above Cobb-Douglas production regression function specified as: 


$$
\ln Y i=\ln A+\sum_{i=1}^{n} \beta i \ln x i+\sum_{j=1}^{n} \beta i x i
$$

Where: $\ln \sum_{\mathrm{i}=1}^{\mathrm{n}} \beta i \ln x i$ is the continuous variable in the form of $\ln , \sum_{\mathrm{j}=1}^{\mathrm{n}} \beta i x i$ is the dummy/categorical/ variable. The $\log$ linear form of the above model was described as:

$$
\begin{gathered}
\operatorname{lny}=\ln \mathrm{A}-\beta 1 \ln _{X 1}+\beta 2 \ln _{X 2}+\beta 3 \ln \mathrm{X}_{3}+\beta 4 \ln \mathrm{X}_{4}-\beta 5 \ln \mathrm{X}_{5}+\beta 6 \ln \mathrm{X}_{6}+\beta 7 \mathrm{X}_{7}+\beta 8 \mathrm{X}_{8}+ \\
+\beta 9 \mathrm{X}_{9}+\beta 10 \mathrm{X}_{10}+\beta 11 \mathrm{X}_{11}+\varepsilon i
\end{gathered}
$$

Where: $\ln Y_{\mathrm{i}}$ is quantity of onion production supplied to the market, $\mathrm{X}_{1}$ is age of house hold head (AGHH), $\mathrm{X}_{2}$ is family size of house hold head (FAMZ), $\mathrm{X}_{3}$ is farming experience of house hold(EXPR), $\mathrm{X}_{4}$ is farm size allocated for onion production (FSA), $\mathrm{X}_{5}$ is distance from the market (DNMKT), $\mathrm{X}_{6}$ is quantity of fertilizer utilized (QFU), $\mathrm{X}_{7}$ is education level of the household head (EDUHH), $\mathrm{X}_{8}$ is sex of the household head (SHH), $\mathrm{X}_{9}$ is extension service (EXS), $\mathrm{X}_{10}$ is credit access (CRA), $\mathrm{X}_{11}$ is access to irrigation (AIRRG),Ln is Natural logarithm and $\mathrm{A}_{0}$ is Constant.

Table 2: List of explanatory variables used for the analysis

\begin{tabular}{llc}
\hline Definition & Type & Expected sign \\
\hline \hline Sex of the household head & Dummy & + \\
Education level of the household head & Categorical dummy & + \\
Extension service & Dummy & + \\
Irrigation access & Dummy & + \\
Credit access & Dummy & + \\
Farming Experience & Continuous & - \\
Distance from Nearest Market & Continuous & + \\
Farm size allocated & Continuous & + \\
Quantity of fertilizer utilized & Continuous & + \\
Family Size of House hold & Continuous & - \\
Age of house hold head & Continuous & \\
\hline
\end{tabular}

\section{Results and Discussion}

\subsection{Descriptive Analysis}

Sex of household revealed that out of total respondent household's $45.76 \%$ sample of house hold were male and $52.24 \%$ were female. Educational level of small holder farmer showed that $44.92 \% \%$ of the sampled household were illiterate and $22.03 \%$ and $17.80 \%$ attended primary school and junior school respectively, and remaining $15.25 \%$ sample of household were secondary educated households use improved input to get good production and supply more products to the market with the right price, at the right time and to the right place. Credit service is very important instruments for households to purchase inputs, materials, pesticides, hire labors on time at required time and boost the productions compared to non-credit users. With regarding to access $41.53 \%$ sample of small holder farmer have no credit access and $58.47 \%$ sample of small holder farmer were having access to credit service. Out of sample of small holder farmer $61.02 \%$ sample of household reported that they have no access to irrigation service and $38.98 \%$ sample of house hold have irrigation service user. Extension service provision expected to have direct influence on the production and marketing behavior of the farmers. The higher access to extension service the more likely that farmer assumed to adopt quantity onion market supplied and innovation. With regarding to the service $55.93 \%$ sample of household have no access to extension service and $44.07 \%$ of the respondents have access to extension service. Family size of the smallholder families, mean of family size of sampled household was 4.14 with minimum value of 2 and maximum of 9 and standard deviation of 2.06. The average age of sampled of household was 34.05 with the minimum age of 16 and the maximum of 65 and standard deviation of 10.50. The average mean of farming experience for the sample of respondent was estimated 17.30 with minimum of 2 and maximum of 35 and standard deviation of 7.47.

Producer play important role in onion value chain. Mostly they produce for consumption and for selling it to different channels. In the study area there is no constant channels to where farmers sell their products. What input to use, when to saw seed and harvest, how much to consume, and how much to sell by considering the available resources is decided by the farmers in the study area. The average land allocated for onion production by farmers in the production year was 2.92 quintal/ha with a maximum of 6 and minimum of 1.1 and standard deviation of 1.51. Average quantity of onion produced during the survey year was 31.40 quintal with minimum of 5 and maximum of 63 and standard deviation of 15.23 . 
Table 3. Average land holding and onion production pattern

\begin{tabular}{l|c|c|c|c|c}
\hline Variable & Obs & Mean & Std. Dev. & Min & Max \\
\hline \hline $\mathrm{Y}_{\mathrm{i}}$ & 118 & 31.40 & 15.23 & 5 & 63 \\
\hline FSA & 118 & 2.92 & 1.51 & 1.1 & 6 \\
\hline
\end{tabular}

Source: own computation based on data (2018)

Marketing channel is the rout through which agricultural product moves from producer to consumer. The length of channel varies from commodity to commodity, depending on quantity to be moved from producer to consumer demand and degree of regional specialization in the production. Onion marketing channel illustrated were constructed based the data collected in five selected onion producer kebele. The result displays that three marketing channel were identified for onion which were acquired from producer and trader survey. The estimated quantities of production were 2, 056 quintals in the survey year of 2018. Out of this 1,894 quintals were supplied to the market.

\subsection{Econometric Analysis}

Econometric model employed 11 explanatory variables were identified as factors affecting quantity of onion production supplied to the market. Out of these eleven explanatory variable, seven variables were found to be significantly, positively and negatively affecting quantity of onion supplied to the market, such as Age of household head, farm experience, family size of household head, educational level of household head, distance from the nearest market, Credit access and quantity of fertilizer utilized more influenced quantity of onion production supplied to the market.

Education Level of the Household Head (EduHH): This is a categorical dummy variable with a value of one if a household head had been literate and zero otherwise. Educational status of the farmer determines the speed with which he/she likely to adopt quantity of onion market supplied. Those who can read and write stand a better chance of understanding things faster. Moreover, better-educated farmers tend to be more innovative and more likely to adopt the marketing system. The survey results of this study revealed that level of education positively and significantly affect quantity of onion supplied to the market $5 \%$ level of significant that indicate if onion producer gets education, the amount of onion supplied to the market increases by $0.11 \%$ quintal, keeping other factors constant.

Credit access (CRA): This is a dummy variable taking a value of one if the household takes loan and zero otherwise. As hypothesized the influence of credit access on marketed surplus of onion was positive. The result revealed that those who have got credit access would increase the quantity of onion production supplied to the market by $0.094 \%$ quintal, keeping all other things to be constant.

Farming Experience (EXPR): it is a continuous variable measured in number of years and have positive relationship with dependent variable. In this study farming experience have a positive and significant effect on quantity of onion production supplied to the market at $1 \%$ level of significantly. The result of this study showed that a one-year increase in experience of onion, production lead to increase elasticity marketable supply of onion by $15.43 \%$, keeping other things to be constant. Farmer with loner period of experience in production was assumed to have a better knowledge than those who have lower experience in farming, because through time producer acquire skill about marketing and supply better than those who has less experienced.

Distance from Nearest Market (DNMKT): This is continuous variable, measured in walking hours from household residence to the market center. In this study distance from the nearest market have negative and significant effect on quantity of onion production supplied to the market. The result of the study revealed that a one hours increase in distance of house hold residence from the nearest market center the, probability elasticity marketable supply of onion was decreased by $26.78 \%$ keeping other things constant. This is because of those households who was closer to the market assumed to have more probability of choosing better market outlet, the lesser would be the transportation charges, reduced walking time, and reduced other marketing costs, better access to market information and facilities.

Quantity of fertilizer utilized (QFU): It is a continuous variable measured in quintals and represents the quantity of chemical fertilizer applied in onion production per ha of land. In this study variable were theorized to affect quantity of onion supplied to the market positively and significantly at $1 \%$ level of significantly. The result of the study revealed that one percent increase in quantity of fertilizer utilized lead to increase elasticity marketable supply of onion by $35.5 \%$, keeping other explanatory variable constant.

Family Size of Household (FAMZ): This is a continuous explanatory variable and refers to the total number of family in the household. In this study family size had positive and significant impact on quantity of onion supplied to the market at $1 \%$ level of significant. In general, the result of this study revealed that, when the number of family increased by one percent the elasticity of marketable supply of onion changed by $29.47 \%$ keeping other explanatory variable constant, this is because the more number of family members an individual had the more probable to produce and more supply to the market.

Age of house hold head (AGHH): This a continuous variable measured in year and have negative and significant 
effect on quantity of onion production supplied to the market, because as one becomes old result's decline in mental and physical abilities lead to deterioration in the production and hesitant to take up new technologies or it also assumed that as age increase the production capacity will decrease and amount of marketed supply decline. Generally, the result of the study showed that when age of house hold increase by one year or percent, elasticity of marketable supply of onion were decreased by $31.22 \%$ keeping other explanatory variable constant.

Table 4: Estimation result of Onion production technology adoption binary logit model

\begin{tabular}{|c|c|c|c|c|}
\hline Variable & $\begin{array}{c}\text { Robust } \\
\text { Coefficient }\end{array}$ & Std. Err. & t-value & $\mathbf{P}>|\mathbf{t}|$ \\
\hline $\begin{array}{l}\text { EDUHH } \\
\text { CRA } \\
\text { IRGA } \\
\text { EXS } \\
\text { SHH } \\
\text { lnAGHH } \\
\text { lnFAMZ } \\
\text { lnEXPR } \\
\text { lnFSA } \\
\text { lnDNMKT } \\
\text { lnQFU } \\
\text { Cons } \\
\end{array}$ & $\begin{array}{l}.1111362 * * \\
.0945382 * \\
.0396906 \\
.0334062 \\
.0709365 \\
-.3122955^{* * *} \\
.2947059 * * * \\
.1543432 * * * \\
.0808464 \\
-.2678653 * * * \\
.3550103 * * * \\
3.224646 \\
\end{array}$ & $\begin{array}{l}0538869 \\
.0554663 \\
.0471798 \\
.0590697 \\
.0522979 \\
0878184 \\
.1179509 \\
.0598593 \\
0565404 \\
0899874 \\
0961118 \\
3514197 \\
\end{array}$ & $\begin{array}{l}2.06 \\
1.70 \\
0.84 \\
0.57 \\
1.36 \\
-3.56 \\
2.50 \\
2.58 \\
1.43 \\
-2.98 \\
3.69 \\
9.18 \\
\end{array}$ & $\begin{array}{l}0.042 \\
0.091 \\
0.402 \\
0.573 \\
0.178 \\
0.001 \\
0.014 \\
0.011 \\
0.156 \\
0.004 \\
0.000 \\
0.000 * * * \\
\end{array}$ \\
\hline
\end{tabular}

Source: own computation based on data (2018).

Obs $=118$ Prob $>$ F $\quad 0.0000^{* * *} \quad \mathrm{~F}(11,106) \quad 41.87^{* * *} \mathrm{P}<0.01,{ }^{* *} \mathrm{P}<0.05$ and ${ }^{*} \mathrm{P}<0.10$

Multicollinearity problem arises due to a linear relationship among independent variables; and becomes difficult to identify the separate effect of independent variables on the dependent variable because of the existence of strong relationship among them. VIF has been used to check the existence of multicollinearity problem among explanatory variables. The test result showed that all values of VIF were less than ten 10 . The mean of variance of inflation factor (VIF) was 1.96 , which indicates no multicollinearity problem among explanatory variables.

\section{Conclusion and Policy Implication}

\section{Conclusion}

This study was aimed to investigate the value chain analysis of onion market in south bench Woreda in Bench Maji Zone. In order to adders the objective of the study both primary and secondary source of data were used with cross- sectional data. The primary data was collected from onion producers and trader (wholesaler and Retailer) using questionnaire and focus group discussion with key informant and Secondary source of data was collected from published article and unpublished reports of different level of agricultural bureau. Descriptive and econometric model were employed to achieve the objective of the study. The study applied cross sectional household level data collected in 2018 cropping season from 118 samples farming household head. Descriptive statistics were used to measure frequency, mean, percentage, and standard deviation. In particular, Cobb-Douglas production function modal were used to identify factor affecting quantity of onion production supplied to the market by farm. The main factors influencing quantity of onion supplied to the market are the quantity of fertilizer utilized, distance from the nearest market, family size of house hold head, educational level of house hold head, farming experience and Credit access. Facilitate the production of onion in generating income in short period, better productivity in small land and use it as cash income source. Government suitable agricultural police designed to support farmer at grass root level especially emphasis given for horticultural production in growth and transformation plan and deployment of development agent. Therefore, it is used to scaling up the best quantity of onion production supplied to the market to other farmers can be considered as one option while introducing new agricultural quantity of onion production supplied practices and technologies is another option.

\section{Policy Implication}

Understanding the factors that influence quantity of onion production supplied to the market is essential in planning and executing technology related programs for meeting the challenges of onion production in our country. Therefore, to enhance improved quantity of onion production supplied to the market by farmers, it's important for policy makers and planners of quantity of onion production supplied to the market to understand farmers need as well as their ability to quantity of onion production supplied to the market in order to come up with onion production that will suit them. It is better to encourage quantity of onion production supplied to the market because the results of this study signified that quantity of onion production supplied to the market increase substantially of the producers. The agricultural research and extension activities need to consider additional agronomic practices along with the quantity of onion production supplied to the market in order to increase onion production, and for the successful promotion, adoption and scaling up of good agronomic practices and extension should contact 
farmers individually as well as in group to be awarded in terms of quantity of onion production supplied to the market is suitable to improve household income.

The improved access to diversified and qualified agricultural onion inputs still remains critically important. Therefore, local government with together regional should supply quantity of onion inputs on the time for farmers through creating awareness on recommended amounts.

Quantity of fertilizer utilization is important in order to increase their productivity and improve livelihoods of smallholder's farmers. As smallholder's farmer they were highly constrained in cash; did not have enough money as a result lack of providing credit service reduce thre application of fertilizer and they are forced to purchase chemical fertilizer for the sake of fulfilling the sales targets at the Woreda level. To promote the quantity of onion that is produce and supply concerned bodies should reduce the cost of chemical fertilizers and providing subsidies through loan service is better option to make them cheap for purchase to increase productivity with per unit area of land. Distance from the nearest market is another problem for the farm in the marketing of onion crop, as the result the concerned bodies should improving rural infrastructure such as road and transportation facilities. Market infrastructure in agricultural level it is important for poor smallholder farmer in enhancing product and to increase market supply of the product.

Increasing the number of cooperatives organization in the rural area in which the farmers will be able to get credit are basis in enhancing the quantity of onion production supplied. Further, it is apparent from the study that if farmers get credit more easily, increase quantity of onion production supplied. Thus, the credit facility should target poor farmers especially those who were not use quantity of onion production supplied due to lack of operating capital. This may encourage the farmers to do commercial farming practice in which they can build their asset to implement quantity of onion production supplied on their farms. Improved quantity of onion production supply involves the use of different practices, which require knowledge, and skill of application and management. Education was found to have a strong relation with the quantity of onion production supply as it enhances onion production. Therefore, due emphasis has to be given towards strengthening rural farmer's education at different levels for small farm households using farmers training centers.

\section{Reference}

1. World Bank (2014). Ethiopia poverty Assessment. Document of the WB for official use only.

2. MEDAC. (1999). Survey of the Ethiopian Economy Review of post-Reform Development (1992/93-1997). Addis Ababa, Ethiopia.

3. ATA. (2014). Agricultural Transformation Agency,PASDEP. Transforming Agriculture in Ethiopia,annual report., $\mathrm{Pp} 3-8$.

4. EHDA. (2011). Exporting fruit and vegetable from Ethiopia. Ethiopia: Ethiopian Horticulture Development Agency.

5. Weldemariam S. Kebede W, and Wassu M. (2015). Growth Parameters of Onion (Allium Cepa L. var. Cepa) as Affected by Nitrogen Fertilizer Rates and Intra-row Spacing Under Irrigation in Gode, South-Eastern Ethiopia. Agriculture, Forestry and Fisheries, 239-245.

6. Bonabana, J. (2013). The performance of potato markets in South Western Uganda. Journal of Development and Agricultural Economics, Vol.5(6), pp225-235.

7. Bezabih E. (2010). Market Assessment and Value Chain Analysis in Benishangul Gumuz Regional State, Ethiopia. Addis Ababa, Ethiopia: SID-Consult-Support Integrated Development.

8. Take more C. Victor A, and Raul P. (2014). Value Chain Analysis of Traditional Vegetables from Malawi and Mozambique. International Food and Agribusiness Management Review Volume 17 Issue 4, 2014.

9. Schmitz H. (2005). Value Chain Analysis for Policy Makers and Practitioners. Geneva, Switzerland: International Labour Office and Rockefeller Foundation.

10. Kaplinsky R. and Morris M K. (2000). Globalization and Unequalization: What can be Learned from Value Chain Analysis. Journal of Development Studies,37(2), 117-146.

11. Anandajayasekeram P. and Berhanu G. (2009). Integrating Innovation Systems Perspective and Value Chain Analysis in Agricultural Research for Development: Implications and Challenges. Improving Productivity and Market Success (IPMS) of Ethiopian Farmers Project,. Nairobi, Kenya.: Working Paper 16. ILRI.

12. Kodigehalli B. (2011). Value Chain analysis for Coffee in Karnataka, India. M.Sc. Thesis,. Berlin, Germany, pp 76.: Humboldt University.

13. CSA. (2014). Large and Medium Scale Commercial Farms Sample Survey Results. Volume VIII: Statistical Report on Area and Production of Crops, and Farm (Private Peasant Holdings, Meher Season). Addis Ababa, Ethiopia.: Federal Democratic Republic of Ethiopia Population Census Commission.

14. FAO. ( 2005). FAO Production year book 2006. Basic data unit statistics division, FAO, Rome, Italy, pp125127.

15. ETFRUIT. (1992). Annual report for the period 1987-1992. addis ababa, 46-58.

16. Lemma D, and Shimelis A. (2003). Research Experiance in onion producation .resaarch report NO 55.Ethiopia 
Agricultural Research Organizational. Addis ababa: EARO.

17. Acquaah G. (2015). convenational plant breading principle and techaniques advance in plant breading strtagies. breading, Biotechanology and Molcular tool, 115-158.

18. Almaz G. Workneh N. Edilegnaw W, and Gezahegn A. (2014). Constraints of Vegetables Value Chain in Ethiopia: A Gender Perspective. International Journal of Advanced Research in Management and Social Sciences, 3:, 2278-6236.

19. Philips B, and Tadesse D. (2007). Ensuring Small Scale Producers in Ethiopia to Achieve Sustainable and Fair Access to honey markets, International Development Enterprises and Ethiopian Society of Appropriate Technology. Addis ababa.

20. Kassa., B. (2014). Factors Affecting Milk Market Participation and Volume of Supply in Ethiopia. Holota Agricultural Research Center, EIAR, Addis Ababa, Ethiopia. Asian Journal of Rural Development, 1996336X,Malaysia.

21. Gebremedhin w., Endale G. and Berga L. (2008). Overview of Trends in Root and Tuber Crops Research. In Root and Tuber Crops: The untapped Resources, Pp. 1-5 in: Gebremedhin Woldegiorgis, Endale Gebre and Berga Lemaga ((Eds.) Ethiopian Institute of Agricultural Research (EIAR), Addis Ababa.

22. Mahilet M. (2013). Value Chain Analysis of Malt Barley: The Case of Tiyo and Lemu-Bilbilo Districts in. Haramaya,: Haramaya University.

23. Kassa., B. (2014). Factors Affecting Milk Market Participation and Volume of Supply in Ethiopia. Holota Agricultural Research Center, EIAR, Addis Ababa, Ethiopia. Asian Journal of Rural Development, 1996336X,Malaysia.

24. Ayelech T. (2011). Market Chain Analysis of Fruits for Gomma Woreda, Jimma zone, Oromia National Regional State. Haramaya, Ethiopia.: Haramaya University.

25. Abebaw M. and Girma D. (2012). Patterns and determinants of livestock farmers' choice of marketing channels: Micro-level evidence. Addis Ababa Ethiopia.: Ethiopian Economics Association.

26. Riziki J. Mlongo P, and Mwanarusi S. (2015.). Determinants of Choice of Marketing Outlets for African Indigenous Vegetables among the Agro-Pastoral Maasai of Narok and Kajiado Counties of Kenya. Journal of Economics and Sustainable Development, 6 (8):, 2222-1700.

27. Chalwe, S. (2011). Factors Influencing Bean Producers ${ }^{\text {ee }}$ Choice of Marketing Channels in Zambia. A Research Report for Award of BSc Degree at University of Zambia, 60pp.

28. Yimer A. (2015). Factors affecting fruit supply in the market: The case of Habru district North Wollo, Amhara Region, Ethiopia. Journal of Marketing and Consumer Research,7:, 35-44.

29. Tadesse N. (2011). Value chain analysis of vegetables in Daro Lebu district of West Hararghe zone, Oromia Region Ethiopia. Haramaya Ethiopia,: Haramaya University.

30. Habtamu G. (2015). Analysis of potato value chain in Hadiya zone of Ethiopia. M.Sc. Thesis,. Haramaya Ethiopia,: Haramaya University

31. Tewodros T. (2014). Factors influencing market participation decision and extent of participation of haricot bean farmers in Meskan District, Ethiopia. M.Sc. thesis. Njoro, Kenya: Egerton University.

32. Yamane T. (1967). Statistics: An Introductory Analysis, 2nd Ed.,. New York: Harper and Row.

33. Mendoza G. (1995). A primer on marketing channels and margins,In G.J.Scott(eds). Prices, products and people: Analyzing Agricultural Markets in Developing countries. International Potato center.Bowlder, London, Pp 257-275. 